\title{
Indonesian Students' Voice about Their Right to Participation at School: Expectation and Reality
}

\author{
Mauly Halwat Hikmat ${ }^{*}$, Aryati Prasetyarini, Muhammad Thoyibi \\ Universitas Muhammadiyah Surakarta, Surakarta 57102, Indonesia
}

Received January 6, 2020 ; Revised June 18, 2020; Accepted June 27, 2020

Copyright $\odot 2020$ by authors, all rights reserved. Authors agree that this article remains permanently open access under the terms of the Creative Commons Attribution License 4.0 International License

\begin{abstract}
Students' right to participation at schools is one of children's rights according to the Child Rights Convention proclaimed by UNESCO which has been adopted in Indonesia. The research investigated: 1) students' knowledge about their rights to participation at school, 2) students' perception about the exercise of their rights to participation covering the scope of their participation and their expectation about the exercise of their rights to participation at school, and 3) students' attitude toward the gap between their expectation and the reality. The participants were 100 students of four high schools at Surakarta, Indonesia. The data were collected through focus group discussion and questionnaires and were analyzed inductively referring to Lundy's model of participation and Pérez-Expósito. The findings showed that the meaning of the right to participation for the students was the right to take part in any school activities including making decision. Students perceived that schools had the basic participation requests in terms of space, voice, audience, and influence. Looking at the gap between the expectation and the reality, most of the students accepted the gap while the rest tried to communicate their aspiration to the teachers. Only a few students did not care about it. However, it is recommended that schools hear the students' voice especially in making decision in a decision making situation. The students' influence should be enhanced by taking their voices into account.
\end{abstract}

Keywords Students' Participation, Space, Voice, Audience

\section{Introduction}

Child rights to participation is one issue of three basic rights of children, which is known as the three p's, namely, provision, participation, and protection. This issue is stated in article 12 in United Nations Convention on the Rights of the Child [1], that children have the rights to express their view without any pressure and force. In Indonesia, the Government has been aware of the importance of the exercise of students' right to participation and has supported the implementation of women empowerment and child protection regulation. It is stated that children have the rights to be involved in making decision related to them which is carried out on the basis of awareness, understanding and willingness so that children can enjoy the results or benefit from the decision (State Minister for Women Empowerment and Child Protection Number 3/2011) [2].

As one of the aspects of the development in Indonesia, education has also been developed referring to the rights of the children. Indonesia has declared a policy about the model of children participation in public policy including their participation in the community, such as congress of children, children forum, and thematic children meeting. Some research had been conducted related to the children participation in Indonesia context. Rizki, Sulastri, \& Irfan (2015) [3] investigated the accommodation of child right through the forum of children in the implementation of child-friendly city of Bandung. Another research was conducted by Azzahra (2017) [4] focusing on community's participation in fulfilling child rights. She found that the community participated in the accommodation of child rights in education, health and protection by conveying ideas.

Other research about children right to participation had also been conducted in other countries, attempting to understand children and young people's participation in schools (Devine, Fahie, \& McGillicuddy, 2013 [5]; Lundy, 2007 [6]; de Castro, 2012 [7]; Gilleece \& Cosgrove, 2012 [8]; Fleming, 2013) [9] as well as in community contexts Percy-Smith, 2010 [10]; Percy-Smith \& Burns, 2013) [11]. However, only a few studies conducted were concerning about the students' rights to participation based on students' perception, including their voice about their participation at school and reaction to the gap between their expectation 
and reality. Research appears to indicate that most children and young people are more concerned that participation is meaningful and that decisions are explained to them rather than that their views are always acted upon (Davey, Burke, \& Shaw, 2010) [12]. Furthermore, in Indonesia, there is a tendency to a top-down and adult-oriented approach to children matters, therefore, it is interesting to conduct research on the students' voice about their rights to participation. It is important to understand children's knowledge, values and experience about their participation in school, which would help the government, policy makers, and school management to improve planning and design of those children's spaces.

\section{Review on Related Literature}

The article 12 of Child Rights Convention has been interpreted by Lansdown [13] as the participation to express a view freely, to be heard in all matters concerning and relevant to children regardless their age and maturity. Involving children in participating some activities relevant to them has many benefits as well as goals. Sinclair (2004) [14] stated that the goals of giving opportunities for children to participate are to protect children's rights; to train them to be responsible legally, to improve services; to enhance decision-making; to promote the protection of children; to empower them. Related to children and education, Matthews (2003) [15] stated that children's participation will facilitate children to adjust themselves with the society and strengthen their relation with adults. The experience to participate will make children get new skills, improve their confidence, enhance relations, and networks (O'Kane, 2003) [16].

Child participation has some benefits in big scope for the country, the community, and for children themselves. For the country, child participation can be a vehicle for preparing new leaders. For the community, child participation can reduce cases of violence against children, because child participation can easily lead to more attention to children, and the voice from children therefore will closely heared. No child violance is one of the voices. For the children, community can (a) help them increase self-esteem and self-confidence, (b) develop talent and skills, (c) develop the ability to take part in challenging neglect or violence against children's rights(d) enhance respects for their rights, (e) increase access to opportunities, (f) develop a 'sense of empowerment', and (g) promote the protection and fulfillment of their rights.

There were some theories about students' participation. Hart (1992) [17] proposed Ladder of Participation which classified the degree of child participation into eight levels based on the degree of children's roles in participation, starting from manipulation of children participation up to children-adult sharing of decision making. Treseder (1997) [18]_proposed five 'degrees of participation' which include: i) assigned but informed, ii) consulted and informed, iii) adult-initiated, shared decisions with children, iv) child initiated, shared decisions with adults, and v) child initiated and directed. Shier [19] suggested Pathways of Participation which covered five levels, namely, (i) young people are listened to, (ii) young people's view are taken into account, (iii) young people's view are taken into account, (iv) young people are involved in decision making process, and (v) young people share power and responsibility in decision making.

On the other hand, Lundy (2007) [6] proposed Model of Participation. The present research study uses Lundy's Model of Participation which suggests that participation include four factors, namely, space, voice, audience and influence. Space means providing an opportunity for children to participate and get involved in an activity. Therefore, children can choose to participate or even not to participate. Voice refers to 'cluster of intentions, hopes, grievances, and expectations that children guard as their own' Audience: A 'right of audience' is described as ' $a$ guaranteed opportunity to communicate views to an identifiable individual or body with the responsibility to listen'. Influence refers to the effect of the children's participation on the outcome of their activities or the children's voice is acted upon.

Related to the scope of participation, there are five scopes of child participation as proposed by Pérez-Expósito [20]. They are 1) binding decision-making: the children are given the opportunity to be heard and their voice influences decision-making school governance, curricular and pedagogical decisions, and the definition of community problems; 2) conflict resolution: The opportunity to involve children in the resolution of the conflict among students or teachers; 3) Knowledge construction: Students are allowed to construct their own knowledge so that the learning process is meaningful for them; 4) Resolution of community problems: Students participate in the resolution of problems in any community they belong, and 5) identity construction. Students are given an opportunity to identify themselves about their own view, preference, and their own subjectivity.

As the primary spirit of the article 12, in making decision, Skivenes and Strandbu (2006) [21] proposed general procedures of involving children in decision-making. Decision making is a process of making a choice from a number of options to meet an expected result (Eisenfuhr, 2011) [22]. Skivenes and Strandbu (2006) proposed that children should be given the opportunity to form their opinions in a decision-making situation. Their voice should be acted out and considered in making decision. This decision should be informed to them including the results. Involving children in making decision, according to Chawla (2001) [23] and Kirby, Lanyon, Cronin, \& Sinclair (2003) [24], can increase self-confidence, give them new skills, increase understanding of democratic values and behaviors, sense of belonging, capability of 
program and policy designing, improve quality of children life, increase sense of community, practice children's rights in real life, and new social networks.

This research used Lundy's theory (2007) to see whether the students' perspectives about participation in school are in line with the model proposed by Lundy and Skivenes and Strandbu (2006) and whether according to the students the schools can be categorized as four factors of participation. To evaluate the extent to which students participate in their schools, this research refers to the theory about the scope of participation as proposed by Pérez-Expósito (2015).

\section{Research Method}

The research was conducted in Surakarta municipality, Central Java, Indonesia. Surakarta municipality has just gained a title as a child-friendly city. It is interesting to find out how the students think about their schools related to providing opportunities for them to participate at school.

Public high schools in Surakarta indicated the significant role of private schools in the Indonesian system of education. Less than one fourth $(21 \%)$ of the existing public schools were state owned schools, while the majority (79\%) of the schools were private schools. Of the $79 \%$ private schools, $17 \%$ of which were owned by non-religious institutions, $41 \%$ by Islamic institutions, $10.5 \%$ by Catholic institutions, and another $10.5 \%$ by Christian institutions. The sample schools used in this research were taken from these five categories, one school for each category. The sample schools were selected by means of convenience sampling (Sekaran, 2003) [25], despite the differences among the public schools in each category.

The data were collected through questionnaires, which were validated through triangulation using different techniques, namely Focus Group Discussion and Interview. The questionnaires consisted of nine open ended questions. The questions were used for exploring the students' perspectives about their rights to participation at school, its enactment in school and their response toward the gap between what they expected and what exercised in practice. The questions were related to the students' understanding about their rights to participation (Question 1), the students' perspective about the students' participation in school (Question 2). Questions 3- 7 were about the scope of their participation at school. Question 9 was about their expectation of the exercise of their rights to participation at school and their response of the gap between what they expected about the accommodation of their rights to participation and the reality, and question 10 was about whether or not the school gave them the opportunity to participate in the classroom and school management.

The subjects of the research were the students of the tenth and eleventh grades of the five selected schools. As many as 20 students from each school were selected to be the subjects of the research. They were selected based on their participation in the intra-school student organization. It was assumed that students involved in the student organization structure were more proficient in articulating their ideas. They were also invited to participate in the Focus Group Discussion and interview with similar questions. To ensure that their rights were not violated, the subjects were given freedom to choose whether or not they would like to participate in the project and were required to give their consent signed by both the participants and their parents. The FGD was held to confirm the data obtained from the questionnaire. The topic being discussed were in line with the questions in the questionnaires.

The data from both instruments were then analyzed through some steps consisting of reducing the irrelevant data, displaying them and drawing conclusion (Miles \& Huberman, 1994) [26]. The data obtained from questionnaires were compared to the data taken from focus group discussion and interview to find out the patterns and common themes that emerged in responses dealing with specific items and to find out whether there were any additional data to be collected. The pattern and theme found from the data were then interpreted and concluded.

\section{Results and Discussion}

The students were interviewed and gathered in a focus group discussion to get the data about 1) their knowledge about their rights to participation, 2) the students perception the exercise of their rights to participation covering the scope of their participation and their expectation about the exercise of their rights to participation at school, and 3) their attitude toward the gap between their expectation and the reality. Students also thought that schools should not force students to participate if they did not want to.

\section{A. Students' knowledge about their rights to participation}

According to the students, the right to participation is the freedom to take part in any activities they like $(100 \%)$, including expressing opinion (78\%), rights to be heard and responded $(5 \%)$, and getting involved in making decision about the rules or the school policy (84\%).However, students (5\%) said that they must know their limit, obey the rules and manage the time for studying. Students thought that participation is the decision of each student. The small percentage of the students' knowledge about their right to be heard indicated the strong paternalistic orientation of the Indonesian, especially the Javanese, culture in which social interaction was hierarchical affirming the virtues that children should listen rather than be listened to. This confirmed the similar study in another county (Bosisio, 2012) [27] demonstrating the reluctance of the culture to give the child the right to be heard. 
The reasons why they need to exercise their right to participation were because 1) the students are part of school residence (20\%) and 2) it will improve their quality of human being. Based on the students' answers, by taking part in any activities, they thought that they would be able to solve their problems in life, to socialize with others, to express their view, to get new experience, to develop interests and talents, and to be brave and more responsible.

The students' understanding about their right to participation is in line with the spirit of the article 12 of Convention of Child Rights as it is the freedom to express their view freely, without any force. The benefits of their participation covers the benefits as mentioned in the state minister for women empowerment and child protection regulation and in line with what Sinclair (2004)[14], Matthews (2003)[15] and O' Kane (2003)[16] that the children's participation will empower them, make them more responsible, improve their confidence, enhance relations, and networks (O'Kane, 2003)[16].

\section{B. Students' perception about the exercise of their right to participation at school}

Of the 100 students who were interviewed, $53 \%$ thought that the school had given them freedom to join in any activities provided at school, both intra curricular and extracurricular activities. Based on the analysis, the findings can be classified into two kinds: the participation in activities and the participation in expressing opinion and decision making. Related to the scope of participation, the scope of participation at school as perceived by the students can be classified into 1) binding decision-making: the children area given the opportunity to be heard that their voice influences decision-making school governance, curricular and pedagogical decisions, and the definition of community problems; 2) Knowledge construction: students are allowed to construct their own knowledge so that the learning process which is meaningful for them, and 3) identity construction: students are given an opportunity to identify themselves about their own view, preference, and their own subjectivity.

\section{Binding-decision making}

All of students thought that their school has made them participate in making decision in small scale, namely, setting classroom rules and expressing their opinion and voice about school matters:

Student C: "We usually set the rules of our classroom, for example, in arranging the seat, and rules that we should change the seat every week. We also arrange the schedule of cleaning team to clean the classroom every day. Furthermore, although the students are given a chance to participate in those activities, the teachers still play their roles as the initiator who decide the procedures as stated by student AC, "The teacher informs us the rules of how to choose the leaders, how to arrange the seat, etc.". This finding confirms the finding stated in the appendix of the state minister for women empowerment and child protection regulation number $3 / 2011$ about child right to participation in the development. As stated in the appendix of the regulation, the participation of students at school is initiated by the teacher. For example, while choosing class leader, the teacher makes procedures and students choose class leaders based on these procedures, etc. This also happens in making school regulations. All regulations are made by the school, where students stay obedient only. Student Council is asked for input in making regulations based on the results of School Board meetings.

Another form of students' participation is the participation to speak up their voice that can be heard by the school management.

Student B: "We have a regular event called "aspiration day" when all students are given the opportunity to express their aspiration in written through questionnaires which is then followed up by the teachers".

Student D: We also have another regular program, called "SMANSA Berbicara"

(The school talks) in which the students can express their opinion orally.

However, the participation of students in making decision has not been covering broader area, i.e., school policy. The programs such as "Aspiration day" and "The School Talks" are the media for the school to hear the students' voice about many things that are not necessarily related to the school needs. However, the students' voice can perhaps be considered while deciding a school policy.

The students' participation in making decision at school as perceived by the students has met some procedures as proposed by Skivenes and Strandbu (2006). Students have been given the opportunity to form their opinions. Their opinion is also expressed in a decision-making situation. However, the situation of decision making is in a small scale compared to the decision making for a school policy. Their situation is in making decision for the classroom regulation or in their school council. For the broader area, their voice is acted upon through regular programs, which are not in a decision-making situation.

\section{Knowledge construction}

All students stated that they were given the opportunity to take part actively in teaching and learning process. They were involved in an active learning procedure in the class.

Student DT: "Usually we are given assignment to discuss the lesson in groups and present the discussion result in front of the class"

Students W: "Teacher always gives us task to discuss the materials in group and then present it in front the class. We the get feedback from our classmates and from the teacher"

The students' answers suggest that teachers have used the suggested method by the National Curriculum used in Indonesia, in which the procedures should use scientific approach which is reflected in discovery learning and inquiry learning. Students construct their own 
understanding and knowledge through their inquiry led by the stimulation from the teacher and confirmed and reinforced by the teachers' feedback at the end.

\section{Identity construction}

All students said that the schools have provided some programs that allow them to join any activities that they are interested in. They identify their own interest and talent and develop themselves and explore their potentials it through some channels.

Student A: "Yes, the school gives freedom for us to choose any club that we want".

Student X: "Yes, we are involved in any activities at school such as "Bulan Bahasa (a month of Indonesian language performance)" school anniversary, and the election of the Head of student organization/student council."

Student Y: "We usually participate in events or program held by both school and the students' organization, such as art festival, Language show, Leadership training, etc."

Student U: "School has many programs such as regular weekend- camping, boy scouts, and celebration of independence day and other national day that we can join freely".

The participation of the students in those activities can be seen as the effort of the school to accommodate the students' rights to participation based on their own interest. This finding shows that school has provided a chance for students to develop their identity construction and explore their identity through the programs provided to the students as proposed by Rich and Schachter [28]. Osguthorpe [29] includes learner identity in his general conceptualization of the relation between learning and identity construction. According to him there are at least five different kinds of identity that are influenced by learning, namely professional, personal, talent, character and learner identity. The provision of school club, extracurricular program such as art festival, language show, leadership training as stated by the students can give them new learning experience. According to Osguthorpe (2006), the learner identity is affected by every new learning experience and he claims that all the other identities revolve around this one. Therefore, by giving these facilities, the school has given the students spaces to construct their identity and develop their capacity.

\section{Students expectation about the exercise of their right to participation at school}

When asked about their expectation of the exercise of their participation, $80 \%$ students thought that they need more spaces to be heard especially in making decision. $5 \%$ of the students' thought that the schools have given enough opportunity for them to participate. $15 \%$ students expected that school should give more time to express their aspiration, so that they could give their voice not only on aspiration day.

\begin{tabular}{|c|c|}
\hline Students' expectation & Percentage \\
\hline Need more space to be heard in making decision & $80 \%$ \\
\hline $\begin{array}{c}\text { The school has given the opportunity for them to } \\
\text { participate }\end{array}$ & $5 \%$ \\
\hline $\begin{array}{c}\text { Need more chance to express their aspiration } \\
\text {. }\end{array}$ & $15 \%$ \\
\hline
\end{tabular}

Student AN: "I hope the school provides students the opportunity to express their own voice all the time, not only on aspiration day or certain program so that teachers can respond our voice immediately"

Although all students think that schools have given opportunity for them to participate in some scopes, most of the students think that the space given by the teacher is not enough regarding their participation in decision making. The students hope that they are invited in a decision-making situation.

This shows that participating in decision making is one thing that most of students expect. According to the human relations model [30], the school should involve its members and make them know that they play important roles, give them a chance to speak their mind related to the decision and their objections. Research conducted by March [31] shows that the involvement of students in making decision process in school contribute to the teachers' and students' high performance in school and strengthen their commitments to school goals and vision.

\section{Students attitude toward the gap between their expectation and the reality}

All the participants were asked about how to deal with the gap between their expectation of the exercise of their participation and the reality that they face. Their responses were varied. $68 \%$ of the students stated that they just accept the gap and choose to be obedient to the rules because they understand the hardship of a school to involve all the students in every decision making. $27 \%$ of the students expressed their expectation to the teachers, and 5\% do not care about the gap.

\begin{tabular}{|c|c|}
\hline The attitude toward the gap & Percentage \\
\hline Accept the reality and be obedient & $68 \%$ \\
\hline $\begin{array}{c}\text { Communicate their expectation with the } \\
\text { teacher }\end{array}$ & $27 \%$ \\
\hline Do not care & $5 \%$ \\
\hline
\end{tabular}

The students' attitude toward the gap as seen in their perspectives show that most of students choose to be obedient to school and do not ask more about their participation (68\%). They just make use of the channels provided by the schools to participate. Some of the students who realize that their voices should be heard are more assertive and make some efforts by conveying their expectation to school. However, since their participation in the other scopes is accommodated, they are not bothered by the gap between what they expect and the reality.

After comparing the students' opinion about the need of 
more chances to participate in making decision, the findings about how the students accept the fact and keep obedient is not surprising since this is related to the assertiveness of the students. Assertiveness refers to one's ability to express and advocate ideas, interests, and feeling easy, appropriately and without anxiety (Lizarraga, et al., 2003) [32]. The opportunities to express their aspiration should be given more often.

\section{Conclusion}

The students' voice is important to be heard as it can improve the quality of students' life, both academically and socially. The students' expectation about their involvement in making decision should be accommodated by schools and be given in a decision situation such as in a specific meeting to hear their voice about the matters being discussed. Schools should formulate in what kind of decision that students can be involved according to their maturity and the important matters of concern. The opportunity for the students to participate should be given in a child-friendly way and should not force the students to participate. and be carefully managed to ensure that the students are free to choose. The findings also indicate that the schools have to train the students' assertiveness so that the school management can hear their voices more clearly. The students can express their ideas, perspectives, feeling, and identify with other people's point of views. The students' aspiration should be facilitated by giving them channels, and can be accessed all the time, as the students' voice may be needed to be followed up immediately.

\section{REFERENCES}

[1] The United Nations, "The United Nations Convention on the Rights of the Child.” pp. 1-14, 1989.

[2] Kementerian Pemberdayaan Perempuan dan Perlindungan Anak, Peraturan Menteri Negara Pemberdayaan Perempuan dan Perlindungan Anak Republik Indonesia. Indonesia, 2011, pp. 1-4.

[3] D. A. Rizki, S. Sulastri, and M. Irfan, "Pemenuhan Hak Partisipasi Anak Melalui Forum Anak Dalam Implementasi Kebijakan Kota Layak Anak Di Kota Bandung (Studi Kasus Forum Komunikasi Anak Bandung)," Share Soc. Work J., vol. 5, no. 1, pp. 11-14, 2015.

[4] Azzahra, "Partisipasi Masyarakat dalam Pemenuhan Hak Anak: Studi Kasus Keterlibatan Gugus Tugas pada Program Kecamatan Layak Anak di Kecamatan Berbah Sleman," UIN Yogyakarta, 2017.

[5] D. Devine, D. Fahie, and D. McGillicuddy, "What is 'good' teaching? Teacher beliefs and practices about their teaching," Irish Educ. Stud., vol. 32, no. 1, pp. 83-108, 2013.

[6] L. Lundy, “"Voice' is not enough: Conceptualising Article
12 of the United Nations Convention on the Rights of the Child," Br. Educ. Res. J., vol. 33, no. 6, pp. 927-942, 2007.

[7] L. R. de Castro, "The 'good-enough society', the 'good-enough citizen' and the 'good-enough student': Where is children's participation agenda moving to in Brazil?," Childhood, vol. 19, no. 1, pp. 52-68, 2012.

[8] L. Gilleece and J. Cosgrove, "Student civic participation in school: What makes a difference in Ireland?," Educ. Citizsh. Soc. Justice, vol. 7, no. 3, pp. 225-239, 2012.

[9] J. Fleming, "Young People's Participation - Where Next?," Child. Soc., vol. 27, no. 6, pp. 484-495, 2013.

[10] B. Percy-Smith, "Councils, consultations and community: Rethinking the spaces for children and young people's participation," Child. Geogr., vol. 8, no. 2, pp. 107-122, 2010.

[11] B. Percy-Smith and D. Burns, "Exploring the role of children and young people as agents of change in sustainable community development," Local Environ., vol. 18, no. 3, pp. 323-339, 2013.

[12] C. Davey, T. Burke, and C. Shaw, "Children's participation in decision-making: A Children's Views Report," 2010.

[13] Gerison Lansdown, Every Child's Right to be Heard: A Resource Guide on the UN Committee on the Rights of the Child General Comment No. 12, no. 12. London: Save the Children, 2011.

[14] R. Sinclair, "Participation in practice: Making it meaningful, effective and sustainable," Child. Soc., vol. 18, pp. 106-118, 2004.

[15] H. Matthews, "Children and Regeneration: Setting an agenda for community participation and integration," Child. Soc., vol. 17, no. 4, pp. 264-276, 2003.

[16] C. O'Kane, Children and young people as citizens, partners for social change: Exploring concepts. Nepal: Save the Children South and Central Asia Region, 2003.

[17] R. A. Hart, Children's Participation: From Tokenism to Citizenship. Florence: UNICEF, 1992.

[18] P. Treseder, Empowering children and young people. London: Children's Rights Office/Save the Children, 1997.

[19] H. Shier, "Partways to participation: Openings, opportunities and obligations: A new model for enhancing children's participation in decision-making, in linne with article 12.1 of the United Nations Convention on the Rights of the Child," Child. Soc., vol. 15, pp. 107-117, 2001.

[20] L. Pérez-Expósito, "Scope and quality of student participation in school: Towards an analytical framework for adolescents," Int. J. Adolesc. Youth, vol. 20, no. 3, pp. 346374, 2015.

[21] M. Skivenes and A. Strandbu, "A Child Perspective and Children's Participation," Child. Youth Environ., vol. 16, no. 2, pp. 10-27, 2006.

[22] F. Eisenfuhr, Decision Making. New York: Springer, 2011.

[23] L. Chawla, "Evaluating children's participation: Seeking areas of consensus," Source PLA Notes, vol. 42, no. 42, pp. 9-13, 2001. 
[24] P. Kirby, C. Lanyon, K. Cronin, and R. Sinclair, Building a culture of participation involving children and young people in policy, service planning, delivery and evaluation. London: National Children's Bureau, 2003.

[25] U. Sekaran, Research methods for business A skill-building approach, Fourth Edi. Danvers: John Wiley \& Sons, Inc, 2003.

[26] M. B. Miles and A. M. Huberman, Qualitative Data Analysis, Second. Thousand Oaks, London, New Delhi: SAGE Publications, Inc., 1994.

[27] R. Bosisio, "Children's right to be heard: What children think," Int. J. Child. Rights, vol. 20, no. 1, pp. 141-154, 2012.

[28] Y. Rich and E. P. Schachter, "High school identity climate and student identity development," Contemp. Educ. Psychol., vol. 37 , no. 3 , pp. 218-228, 2012.

[29] R. T. Osguthorpe, "Learning that grows," Curr. Dev. Technol. Educ., no. 801, pp. 1888-1892, 2006.

[30] R. Miles, Theories of Management; Implications for organizational behavior and development. New York: McGraw Book Co., 1975.

[31] J. G. March, Primer on Decision Making: How decisions happen. New York: Simon \& Schuster, 2010.

[32] M. L. S. de A. Lizarraga, M. D. Ugarte, M. Cardelle-Elawar, M. D. Iriarte, and M. T. S. de A. Baquedano, "Enhancement of self-regulation, assertiveness, and empathy," Learn. Instr., vol. 13 , no. 4 , pp. 423-439, 2003. 